\title{
NEW CONSTRUCTION METHODS AND NEW ROLES FOR ENGINEERS
}

\author{
MiLTON F. LUNCH* \\ I \\ INTRODUCTION
}

Traditionally, a physical facility went from concept to completion under a relatively simple system embodying the virtues of a three-legged stool: the owner provided the outline of the needed facility and furnished the money; the architect/engineer (A/E) expressed that desire in plans and specifications, and the contractor put the physical members in place pursuant to those plans and specifications. Of course, this tripartite relationship was never quite that simple since as problems arose, conflicts had to be resolved and compromises had to be made in order to achieve the result. There were, however, fairly clear lines of authority and responsibility among the three partners of the enterprise.

The emergence of construction management as an important tool in the construction process, particularly in larger and more complex projects, has changed this traditional relationship and raised a number of pertinent issues:

1. What constitutes construction management?

2. What licensing requirements must a construction manager (CM) satisfy?

3. Can an $\mathrm{A} / \mathrm{E}$ or a general contractor simultaneously operate as the CM?

4. What liability concerns can the CM expect to encounter?

This article attempts to highlight the controversies concerning these issues. In particular, the article explores the problems that $\mathrm{A} /$ Es will face as they enter the field of construction management.

II

\section{Definition of Construction Management}

The one, and probably only, area of agreement regarding construction management is that there is no consensus as to what it is, what it ought to be, and how it should be applied.

One may ask why this confusion over construction management exists when its definition appears relatively straightforward. There is little question about the meaning of "construction," and there is fairly common agreement that "management" means the control and direction of something; ostensibly, then, "construction management" denotes the control and direction of construction. Despite this

Copyright (C) 1983 by Law and Contemporary Problems

* General Counsel, National Society of Professional Engineers. 
relatively clear definition, however, the term "construction management" avoids any set meaning.

In connection with this definitional controversy, a leading engineer-lawyer, who has wide experience in the design and management of construction projects, and who is a long-time member of the Engineers' Joint Contract Documents Committee (EJCDC), observed:

$[\mathrm{T}]$ here is a very interesting situation with construction management. It is reasonable to expect that if there were a group of individuals defining construction management, one would come up with a number of different understandings of this subject. And each different understanding has a different legal implication.

There are contractors serving as construction managers with a totally different concept than that proposed by the architects or that proposed by the engineers. In fact, the engineers are so gun-shy, they don't even call it construction management. They call the guys project managers. ${ }^{1}$

One attempt at defining the construction manager's role can be found in the EJCDC's document, Standard Form of Agreement Between Owner and Project Manager for Professional Services. (The document uses the title "project manager" instead of "construction manager"). ${ }^{2}$ The opening commentary of the document explains that the project manager agreement was prepared in response to numerous requests for an agreement that would combine most of the customary functions of a professional engineer with those of a construction manager. ${ }^{3}$ The commentary further explains:

The attached Agreement contemplates the combination of these design and management functions from the start of the relationship with the Owner and the continuation thereof until completion of construction. While carefully coordinating all aspects of his services with the Owner, the Project Manager will take over for the Owner many administrative and coordinating functions. He will, in effect, take charge of the Project from beginning to end in order to provide special expertise and relieve the Owner of duties and responsibilities which the Owner is neither qualified to undertake nor for which he will have a continuing need. However, under the attached Agreement, the Project Manager will not perform any of the functions of the contractors. He may assist in purchasing on the Owner's behalf, coordinate the work of separate contractors and assist in expediting various aspects of the work; but neither in his capacity as a professional engineer nor as a construction manager will he be involved in or assume responsibility for the means, methods, techniques, sequences, or procedures of construction or the safety precautions or programs incident thereto. ${ }^{4}$

The EJCDC project management agreement follows the same format and content as the Standard Form of Agreement Between Owner and Engineer for Professional Services $^{5}$ in spelling out the services of the engineer from project development to preliminary and final design phases, to the bidding and negotiation phases for construction and services during the construction phase. The essential difference

1. Abplanalp, Evaluating Responsibilities, Construction Speciriter, April, 1982, at 20, 23-24.

2. Engineers' Joint Contract Documents Committee, Standard Form of Agreement Between Owner and Project Manager for Professional Services, Doc. 1910-15 [hereinafter cited as EJCDC Project Manager Agreement].

3. Id.

4. Id.

5. Engineers' Joint Contract Documents Committee, Standard Form of Agreement Between Owner and Engineer for Professional Services, Doc. 1910-1 [hereinafter cited as EJCDC Owner-Engineer Agreement]. 
between the two documents, however, is that the project management agreement requires the owner, during construction, to assume the duties of "administration" of construction contracts and "coordination" of the sequence of construction operations. In addition, the agreement contains the caveat:

PROJECT MANAGER shall not be responsible for the acts or omissions of any Contractor(s), any subcontractor(s) or any of Contractor(s)' or subcontractor(s)' agents or employees or any other person (except his own employees and agents) at the Project site or otherwise performing any of the work of the Project. ${ }^{6}$

The American Institute of Architects' Owner-Construction Manager Agreement" similarly reflects the concept that the CM furnishes "business [a]dministration," "management services," and "coordination," as distinguished from actual control and direction of the construction, which is left to the general contractor or separate prime construction contractors.

One of the most comprehensive definitions of construction management and its scope was promulgated by the Federal Government. In late 1980, the Federal Procurement Regulations Directorate, Office of Acquisition Policy, issued for comment a proposal defining construction management for federal agency purposes. ${ }^{8}$ Depending on one's viewpoint, it may represent "the best of both worlds," by having both a broad approach and alternative concepts. The opening definitions illustrate the scope of the proposal:

The following definitions apply to this subpart.

(a) "Construction management concern" means a concern that is an experienced, multidisciplined organization or joint venture qualified to accomplish selected construction management (professional) services. The ability to perform these services is acquired through extensive experience in all phases of the construction process.

(b) "Construction management services" means services that encompass a wide range of professional services relating to the management of a project during the pre-design, design, and construction phases. (These services are deemed to be "professional" in accordance with § 1-3.204 Personal or Professional Services.) The types of services include development of project strategy, design review relating to cost and time consequence, value engineering, budgeting, cost estimating, scheduling, monitoring of cost and schedule trends, procurement, observation to insure that workmanship and materials comply with plans and specifications, contract administration, labor relations, construction methodology and coordination, and other management efforts related to the acquisition of construction. ${ }^{9}$

The proposal also recognizes three categories of construction contractors: ${ }^{10}$ the General Construction Contractor category reflects the traditional three-legged approach of an owner, design professional and one general contractor; the turnkey contractor is responsible for site selection, design, construction, inspection and financing; and the construction management contractor category is divided into the subcategories general and guaranteed maximum price.

Under these options the CM should be employed at the start of planning and

6. EJCDC Project Manager Agreement, supra note 2, § 1.6.13.

7. American Institute of Architects, Standard Form of Agreement Between Owner and Construction Manager, Doc. B801 (1980) [hereinafter cited as AIA CM Agreement].

8. Proposed Regulation on Construction Management (Professional) Services (1981) (to be codified at 41 C.F.R. $\S \S 1-18.500-.506$ ) (proposed Oct. 16, 1981) (available from Federal Procurement Regulations Directorate, Office of Acquisition Policy, GSA).

9. Id. $\S \S 1-18.501(\mathrm{a})-(\mathrm{b})$

10. Id. $\S \S 1-18.502-1$ to -3 . 
the pre-design phase, and continue to project completion. Utilizing this procedure, the CM can assist the government agency in functions such as project planning and budget administration. "Additionally, the $\mathrm{CM}$ is to assist the $\mathrm{A} / \mathrm{E}$, if there is one, in activities such as providing information on materials selection, labor impact, construction techniques, construction sequence, design reviews, bid packaging, scheduling, and other cost-saving techniques. ${ }^{12}$

It is important to note that the CM's services are regarded as "professional," even though the selection process for a CM requires public notice and use of either a formally advertised (bid) procedure, or so-called "competitive negotiations," which include price as a factor in the selection. ${ }^{13}$ The introduction of price in the selection process lends credence to the notion that $\mathrm{A} / \mathrm{Es}$ who want to go into the construction management business will have to depart from their traditional role under a nonprice selection procedure for professional services, as provided by the federal Brooks law. ${ }^{14}$ Therefore, the $\mathrm{A} / \mathrm{E}$ will have to recognize that $\mathrm{CM}$ hiring policies will be conducted under construction business rules, rather than professional rules.

\section{III}

\section{State LiCEnsure ReQuirements}

One of the most important questions concerning construction management is who is qualified to act as a CM. The number of people who could qualify as a CM would be considerably smaller if CMs were required to have a contractor's or an architect's license. In California, for example, the Attorney General concluded that "a construction manager need not be licensed as a contractor or as an architect." 15 In terms of requiring the CM to have a contractor's license, the Attorney General initially noted that "[I]t is unlawful for any person to engage in the business of contracting without a license," 16 and that a contractor is defined as [a]ny person, who undertakes to .. . or submits a bid to, or does himself or by or through others, construct, alter, repair, add to, subtract from, improve, move, wreck or demolish any building, highway, road, parking facility, railroad, excavation or other structure, project, development or improvement, or to do any part thereof. . . ."17

The California Attorney General ruled, however, that the licensure provisions

11. Id. $\S 1-18.505-1(\mathbf{a})$.

12. Id.

13. Id. $\$ 1-18.504$

14. "The [contracting] agency head shall negotiate a contract with the highest qualified firm for architectural and engineering services at compensation which the agency head determines is fair and reasonable to the Government." 40 U.S.C. $\$ 544$ (a) (1972).

15. 57 Op. Att'y Gen. Cal. 421, 422 (1974).

16. Id. at 421 ; see also Cal. Bus. \& Pror. Code $\S 7028$ (West 1975). Many states prescribe the practice of engineering without a license. See, e.g., FLA. STAT. Ann. $\$ 471.031$ (West Supp. 1981); Illinois Professional Engineering Act, § 1, ILl. ANN. STAT. ch. 111, § 5101 (West 1978); MO. REV. STAT. § 327.191 (Supp. 1981); N.J. Stat. AnN. § 45:8-39 (West 1978); Pa. Stat. Ann. tit. 63, § 150 (Purdon Supp. 1982); Tex. Rev. Civ. STAT. ANN. art. 3271 a.1.2 (Vernon 1968). Some states proscribe the practice of contracting without a license. See, e.g., Ark. Stat. AnN. $§ 71-713$ (1979).

17. See Cal. Bus. \& Prof. Code $\S 7026$ (West 1975 \& Supp. 1981). 
did not apply to the CM because "[a] construction manager does not bind himself to construct a building." 18 With regard to the need to have an architect's license, the Attorney General stated,

Supervision of bids from contractors and subcontractors has been held to come under the practice of architecture. Wallich v. Salkin, 219 Cal. App. 2d 157, 161-63 (1963). But supervision of the construction alone, without having drawn the plans and made the designs, is not the practice of architecture, and one may so supervise without being required to have an architect's certificate. ${ }^{19}$

An Arkansas case involved the similar question of whether an $\mathrm{A} / \mathrm{E}$ firm acting as $\mathrm{CM}$ was required to be licensed as a contractor. ${ }^{20}$ An $\mathrm{A} / \mathrm{E}$ firm retained for construction management services was challenged by the Contractors Licensing Board and the state chapter of the Associated General Contractors of America for engaging in construction without having a contactor's license. The chancery court held that "[c]onstruction management is not, per se, in violation of the Arkansas Contractors Law."21 The court noted, however,

[I]n this particular case there was a general contractor who had the supervisory authority, and because of that fact, the services that the defendant undertook to perform, and did perform, under its contract as construction manager . . . do not fall within the definition of 'contractor', as that term is defined in [the state licensing statute], and the defendant was not, therefore, in violation of the Arkansas Contractors Law and not required to have a contractor's license in order to perform such services. ${ }^{22}$

The clear implication of the ruling was that in the absence of a general contractor and a contractor's license, the court might have held that performance of the CM function by the $\mathrm{A} / \mathrm{E}$ firm was an illegal practice of construction.

The licensing board appealed to the Arkansas Supreme Court. While the appeal was pending, however, the legislature amended the contractor licensing law (presumably with the encouragement of the state contractors group) to require a license of any organization which intends "to manage the construction" of any structure $^{23}$ As a result of this legislative change, the state supreme court held the appeal moot. ${ }^{24}$

\section{IV}

\section{CONFLICT OF INTEREST}

From the time that construction management emerged as a major develop-

18. 57 Op. Att'y Gen. Cal. 421, 422 (1974).

19. Id. This decision also raises the concern that a party who performs services in violation of the state licensing laws may face the loss of fees or compensation for those services. For example, a Georgia case held that a contractor licensed only in Tennessee, who provided construction in Georgia, was not entitled to payment. Gorrell v. Fowler, 248 Ga. 801, 286 S.E.2d 13 (1982). For additional cases and comment, see M. Lunch, Licensing Problems for Architects and Engineers and Their Impact Upon Construction Projects (unpublished manuscript) (presented at ABA Forum Committee on the Construction Industry, in Chicago, IIl., Apr. 29-30, 1977).

20. See Contractors Licensing Bd. v. Cromwell, Neyland, Truemper, Levy \& Gatchell, Inc., No. 752468 (Ark. Ch. Apr. 9, 1976).

21. Id. slip op. at 1 .

22. Id. ; see also ARK. STAT. ANN. § $71-713$ (1979).

23. Act of Mar. 23, 1977, No. 684, § 1, 1977 Ark. Acts 1639 (codified as amended at ARK. STAT. ANN. $\S 71-701$ (1979)). The amendment did not address the question of what constitutes managing construction.

24. Telephone interview with Alston Jennings, Esq., of Wright, Lindsey \& Jennings (1977). 
ment in the 1960's there has been a continuing debate over whether the designer and/or the general contractor should be permitted to perform their own roles as well as the role of CM.

Originally, the concept of the CM was that he was solely the agent of the owner, working for a fee without any financial involvement in either the design or the construction. It followed, therefore, that neither the designer nor the contractor could serve in the CM position because each would have either an actual or potential financial interest in the project. One commentator notes, for example, that "a serious conflict of interest" would arise if the CM offers expertise during the decision and design phase and subsequently bids for the construction. ${ }^{25}$ The same author raises the concern in a different way: if the $\mathrm{A} / \mathrm{E}$ designer also serves as the CM, the designer would have a dual role for assessing his own design. ${ }^{26}$

Apparently, the engineering and architectural community did not agree. Their position was that the $\mathrm{A} / \mathrm{E}$ has the traditional responsibility to provide professional services during construction to determine that the contractor is following the plans and specifications for the benefit of the owner, and that this basic loyalty to the owner does not change simply because the $\mathrm{A} / \mathrm{E}$ simultaneously acts as the CM.

In contrast, the Associated General Contractors (AGC), argue that allowing the $\mathrm{A} / \mathrm{E}$ also to serve as the CM would create an inherent conflict of interest by undercutting the value of the CM's impartial advice to the owner during the planning and design phases. This view was articulated in the official AGC magazine:

AGC's position on the conflict of interest matter is that a construction manager who is retained to assist with, among other things, design review and evaluation for a fee over and above the design fee paid to the architect or architect/engineer, is akin to retaining a second doctor for an opinion. The first doctor, no matter how good or dedicated, would not serve the patient well by offering to provide the second opinion himself for an additional fee. The object of the second doctor's opinion is to obtain an independent review, free of unintentional bias which can develop from close association to the patient. The object of the CM's design review services is to call the owner's and design professional's attention to areas of the plans that contain possible ambiguities, errors, omissions, or features that, although correct, may not serve the owner's interest because of construction costs, material costs, or expenses.

AGC believes that the architect/engineer who designs a project not only is prevented from giving the detached review required by a CM, but, as CM, may, in fact face a situation in which he exposes himself to liability as an architect if he does deliver an objective review. If he discovers an error or omission as a CM and does not disclose it, however, then he has violated his contractual duty as a $\mathrm{CM}^{27}$

In 1980 , this controversy over whether a detrimental conflict exists came to a head in the Indiana legislature. The local unit of AGC sponsored a bill which would have prohibited a local government agency from employing an engineer or architect for services for scheduling, budgeting, bidding coordination, consultation on contract awards, and project coordination services when that architect or engi-

25. Sneed, The Construction Manager's Liability, 1981 Construction Litigation 317, 333 (Practicing Law Institute ed.).

26. Id.

27. Reed, CM's Conflict of Interest Question, CONSTRUCTOR, June 1980, at 16, 18. 
neer was also providing design services. ${ }^{28}$ The bill was initially approved by the Indiana House of Representatives and received a favorable report from the Senate Commerce Committee. ${ }^{29}$ However, in the face of strong opposition by the state design professions, the sponsors agreed to a compromise bill, and it was subsequently enacted. ${ }^{30}$ The compromise law prohibits a local governmental unit from employing the engineer or architect who performed the design as the "construction manager" for the same project. ${ }^{31}$ The law, however, defined a "construction manager" as "a person designated as a construction manager by contract who provides professional management services. . .."32 The effect of the emphasized words is that the owner may retain an engineer or architect both to design the project and perform such additional services for the project as budgeting, bidding coordination, consultation on contract awards, and coordination of the work of the contractors. The only restriction is that the engineer or architect cannot be employed for those additional services by means of a separate contract which specifically designates the design firm or an affiliate as a construction manager. ${ }^{33}$

In an earlier case, the attorney general of Arizona was asked by an official of a local school district if it could use a construction manager in lieu of a general contractor to build one or more school buildings. Under the proposal, the school board would contract directly with various trades, such as plumbing and electrical, on the basis of their bids. A management consultant would be hired to control the project and keep the school officials informed as to when bids should be requested from various trades. The Attorney General ruled that such a procedure would be in conflict with state law, which required that school districts, among others, must approve working drawings and specifications for a proposed building, "publish a notice to contractors of intention to receive bids and contract for the proposed work." 34 "These statutes," it was held, "contemplate solicitation and receipt of bids from contractors for the entire project" and require entering into a contract with the lowest responsible bidder. ${ }^{35}$ It was also noted that the proposed procedure failed to comply with the requirements for performance and payment bonds, both of which must be for the "full contract amount."36

In a similar case, the Attorney General of South Carolina was asked whether construction management services may be added by amendment to an existing contract between a public entity and an architectural firm without advertisement for those services. ${ }^{37}$ Replying to the question in the negative, the Attorney General noted that although the regular competitive bidding statute did not apply to

28. H.R. 1280, 102d Gen. Ass., 1st Sess., (1981).

29. Letter from Indiana Society of Architects to Opponents of House Bill 1280 (May 11, 1980).

30. Act of Apr. 27, 1981, Pub. L. No. 60, 1981 Ind. Acts 821 (codified at IND. CODE ANN. § 5-16-10,-1 to -3 (Burns Supp. 1982)).

31. Ind. Code AnN. § 5-16-10-2 (Burns Supp. 1982).

32. Id. \$ 5-16-10-1 (emphasis added).

33. Id. $\$ 5-16-10-2$.

34. Op. Att'y Gen. Ariz. No. $77-192$ (R77-165) at 2 (1977) (quoting ARIz. Rev. STAT. ANN. § 34 201.A (1974)).

35. Id. at 2 .

36. Id. at 3 (construing ARIZ. REV. STAT. ANN. § 34-222.A (1974)).

37. 1980 Op. Att'y Gen. S.C. 60. 
professional services, the agreement for professional services did not contemplate that the architect would act as a construction manager on the project. ${ }^{38}$

It is the opinion of this Office that the use of a construction manager was not contemplated in the original Agreement and that if it had been contemplated, AIA Document B 141/CM, the construction management edition of the standard form of Agreement between owner and architect, would have been utilized. And even that document contemplates a separation of the architect and the construction manager rather than the assumption of a dual role by the architect. ${ }^{39}$

The opinion, therefore, concluded that construction management services should be the subject of advertisement and bidding. ${ }^{40}$

These state attorney general opinions do not necessarily resolve the conflict of interest issue, but they do reflect a recognition of the separate status and roles of designers and construction managers. Pending clarification of the conflict of interest question and depending upon the scope of services and responsibility of the CM, the traditional concept of conflict of interest would appear to bar the $\mathrm{A} / \mathrm{E}$ from also playing the CM role on the same project. This is merely an instance of the traditional maxim that a person may not wear two hats without the possibility of encountering conflicting loyalties.

A more modern approach is that the "two hat" phenomenon is acceptable when all of the facts and circumstances are known and accepted by the principal. For example, the Code of Ethics of the National Society of Professional Engineers, initially provided that " $[t]$ he Engineer will endeavor to avoid a conflict of interest with his employer or client, but when unavoidable, the Engineer shall fully disclose the circumstances to his employer or client."41 After anguishing for some years over the argument that a conflict was almost always avoidable by simply not taking on the assignment in case of doubt, ${ }^{42}$ the drafters revised the Code to require only a disclosure statement: "Engineers shall disclose all known or potential conflicts of interest to their employers or clients by promptly informing them of any business association, interest, or other circumstances which could influence or appear to influence their judgment or the quality of their services." 43

Under the present version, if an owner wants to have the design engineer also serve as CM, it is obvious that he must secure a full disclosure from the engineer concerning any potential conflict. This situation, in which the owner hires an $\mathrm{A} / \mathrm{E}$ to function as designer and CM, is markedly similar to a turnkey approach, which is often used by owners. Is the actual, or potential, conflict substantially different than the situation in which the owner decides to use a turnkey approach for his needs? Similarly, it can be argued that the turnkey method of one firm's doing both design and construction under one contract gives rise to a conflict of interest. In response to the argument, the owners have concluded that they can withstand

38. Id. at 62 .

39. Id. at 62.63 .

40. Id. at 63 .

41. CODE OF EThics fOR ENGineers $\$ 8$ (1974) (National Society of Professional Engineers) (amended 1981).

42. See, e.g., id. app. F.III-2 (advisory opinion of the Board of Ethical Review, Case No. 71-6). (Smith, dissenting).

43. CODE OF ETHICS FOR ENGiNEeRs $\$$ II.4.a (1981) (National Society of Professional Engineers). 
the "conflict" in return for the advantages of single responsibility, efficiency, economy, or whatever other benefits are believed to flow from the turnkey system.

An examination of the federal system provides helpful insight into how the conflict of interests issue might be handled. For example, federal agencies bar the merger of design and construction. The Federal Procurement Regulations provide that "[n]o contract for construction of a project shall be awarded to a firm or person that designed the project, except with the approval of the head of the procuring agency, or his authorized designee." 44 The Defense Acquisition Regulations have a similar provision. ${ }^{45}$

While these restrictions curtail the ability of the $\mathrm{A} / \mathrm{E}$ to function simultaneously as the contractor, they have had a noticeable impact on whether a design professional can also serve as CM on the same project. A Public Building Service study in 1970 defined the CM as one who works with a separate design professional to provide expertise on construction technology, and related services, which eliminates the need for a general contractor, and whose services are obtained on a competitive bid basis. ${ }^{46}$ The latter condition eliminates the possibility of combining the design and CM services in one contract because under the federal Brooks Law $^{47}$ design services must be obtained under a nonbid professional selection and negotiation procedure.

The United States Postal Service (USPS), which operates under its own procurement authority, provides for CM services under a two-envelope procedure requiring separate technical proposals and cost proposals. ${ }^{48}$ However, the USPS policy is straightforward: "Where services of a construction management contractor are to be utilized, it is postal policy that the design firm for the project may not be considered for these [CM] services." 49

\section{$\mathrm{V}$ \\ Liability CONCERNS}

Since the explosion of liability claims against engineers and architects, which is not likely to subside, a prime concern of those engaged in the development of standard contract documents has been to narrow the exposure of the $\mathrm{A} / \mathrm{E}$ as much as possible. The EJCDC documents, ${ }^{50}$ for example, spell out with great precision that the engineer will not make exhaustive or continuous on-site inspections to

44. 41 C.F.R. $\S 1-18.112$ (1981).

45. "No contract for construction of a project shall be awarded to the firm which designed the project or to its subsidiaries or affiliates, except with the approval of the Secretary of the Department concerned." 32 C.F.R. § 18-115 (1981).

46. Public Building Service, General Services Administration, Construction Contracting Systems: $A$ Report on the Systems Used by PBS and Other Organizations 5-1 to 5-2 (Mar. 17, 1970), reprinted in Public Building Service, General. Services administration, The GSa System for Cunstrl'cTION MANAGEMENT (1977).

47. 40 U.S.C. $\$ 544(\mathrm{a})(1972)$; see also supra note 14.

48. U. S. Postal Service, Handbook No. RE-8, USPS Facilities Design and Constrlction Program 16 (1981).

49. Id. at 15.

50. See supra notes 2-6. 
check the quality or quantity of work. ${ }^{51}$ The documents also indicate that the engineer will not be responsible for the means, methods, techniques, sequences or procedures of construction selected by the contractor or for the safety precautions and programs of the contractor. ${ }^{52}$ In reviewing and approving shop drawings, the engineer will be responsible only for "conformance with the design concept," 53 a phrase which has defied clear definition.

These caveats and exculpatory clauses have their basis in a long and troublesome series of court decisions holding design professionals responsible for injuries and failures during the construction phase when the contract stipulated that the engineer would "supervise" the construction. In finding liability, courts ruled, in effect, that the words "supervision of construction" are not words of art and should be accorded their ordinary and usual definition. ${ }^{54}$

While there were some cases absolving the A/E from responsibility for "supervision," 55 those cases extending liability beyond that contemplated by the A/Es has caused them rarely to sign a contract which obligates them to "supervise the construction."

The concern generated by such liability has naturally had an influence on the drafting of contract forms for construction management, or project management, services. The EJCDC project manager agreement not only calls for "administration" of the construction contracts, but it also carries disclaimers as to responsibility for means and methods of construction. ${ }^{56}$

Despite these precautions and the argument that CMs were not engaged in the construction itself, several decisions under the Occupational Safety and Health Act have held construction managers responsible for violations of construction safety standards, notwithstanding the argument of the CMs that they were not engaged in the construction itself and that their function under the respective agreements was merely to "coordinate" the construction. 57 Crucial to the CM's liability is the court's determination that the CM is actually engaged in construction. For example, Bertrand Goldberg Associates, an architectural firm serving as architect and as construction manager, was held "engaged in construction work" and therefore subject to construction standards even though it had contracted to provide normal professional services and performed no construction work. ${ }^{58}$ The OSH Review Commission noted that the architect was within the scope of the act because his agreement to "coordinate" the construction was inextricably intertwined with the actual physical labor at the site and his "position [was] more akin

51. EJCDC Owner-Engineer Agreement, supra note 5, § 1.6.2.

52. Id.

53. Id. $\$ 1.6 .3$.

54. See, e.g., Aetna Ins. Co. v. Hellmuth, Obata \& Kassabaum, Inc., 392 F.2d 472, 477 (8th Cir. 1968); Lee County v. Southern Water Contractors, Inc., 298 So. 2d 518, 520 (Fla. Dist. Ct. App. 1974); Cutlip v. Lucky Stores, Inc., 22 Md. App. 673, 693, 325 A.2d 432, 443 (1974).

55. E.g., Hausam v. Victor Gruen \& Assocs., 36 Ill. App. 3d 1145, 408 N.E.2d 1051 (1980); Moundsview Indep. School Dist. No. 621 v. Buetow \& Assocs., 253 N.W.2d 836 (Minn. 1977).

56. EJCDC Project Manager Agreement, supra note 2, opening commentary.

57. E.g., Bechtel Power Corp. v. Secretary of Labor, 548 F.2d 248 (8th Cir. 1977); Cauldwell-Wingate Corp., 6 O.S.H. Cas. (BNA) 1619 (1978).

58. Bertrand Goldberg Assocs., 4 O.S.H. Cas. (BNA) 1587 (1976). 
to that of a general contractor. . . ."59

Shortly thereafter the OSH Review Commission reached the opposite result in a closely related case. ${ }^{60}$ Skidmore, Owings \& Merrill, an architectural firm, contracted to provide field representatives to "observe" the construction, review tests, and direct correction of improper work. ${ }^{61}$ Its contract disclaimed authority to direct the work of the contractors or supervise construction methods or techniques. ${ }^{62}$ Proving that labels can sometimes make a difference, the OSH Review Commission noted that in this case the architect was not identified as a "construction manager,"63 as in Bertrand Goldberg Associates. ${ }^{64}$ In this case, the Review Commission concluded that "an employer must perform actual construction work or exercise substantial supervision over actual construction. Although [the architect] exercises some supervision over construction we would not characterize it as substantial in the sense that supervision by a construction manager is substantial."65 The Skidmore, Owings $\mathcal{G}^{2}$ Merrill case may give some comfort to A/Es who are careful not to contract for "construction management," as such, but the thin line between the cases may prove illusory when presented in other forums. The key to the CM's liability may lie in two words - "control" and "direct." If the CM has either function, either in contract or in practice, the wise practitioner should probably assume that he may be held liable for construction accidents and failures.

This potential liability for CMs raises the additional issue of whether A/Es can qualify for professional liability insurance for CM functions. Presently, a separate professional liability insurance policy for construction management does not exist. In addition, the earliest professional liability policies for $\mathrm{A} /$ Es excluded from coverage "the performance of services not customary for an architect or engineer." 66 Although later policies issued by Continental Casualty Company, the largest of the $\mathrm{A} / \mathrm{E}$ underwriters, deleted that exclusion, its $\mathrm{A} / \mathrm{E}$ policies only provide liability protection if "legal liability arises out of the performance of professional services for others in the Insured's capacity as an architect or engineer . . . ."67 A somewhat revised policy is also available for "design/construct" by endorsement of the basic policy. ${ }^{68}$ It defines the covered professional services to include "construction manager," but it continues to exclude "[s]cheduling of construction or the means, methods or techniques used in construction." 69 This absence of liability protection for the $\mathrm{A} / \mathrm{E}$ firm which engages in construction management under an agreement obligating the A/E-CM "to plan, organize and control the construction program as

59. Id. at 1589 .

60. Skidmore, Owings \& Merrill, 5 O.S.H. Cas. (BNA) 1762 (1977).

61. Id. at 1763 .

62. Id.

63. Id. at 1764 .

64. See supra text accompanying 58-59.

65. Skidmore, Owings \& Merrill, 5 O.S.H. Cas. (BNA) at 1764.

66. See generally Sneed, supra note 25 , ch. 7.

67. CNA Insurance Co., Architects and/or Engineers Professional Liability Policy, Doc. No. 1-41260A (1982) (available from Schinnerer \& Co., Inc.).

68. Letter from Schinnerer \& Company, Inc. to Milton F. Lunch (July 6, 1981) (enclosing a copy of the policy form utilized for design/construct firms).

69. Id. 
a whole" 70 leaves the contractual $\mathrm{A} / \mathrm{E}$ in a dangerous situation.

\section{VI}

\section{CONCLUSION}

Construction management is just now coming out of its teens, a difficult period of learning and adjustment. Construction management is undoubtedly a technique which is here to stay and likely to be increasingly utilized, particularly in large and complex projects. As A/Es enter the construction management field, they should be aware of the potential pitfalls inherent in this new field and recognize that they are actually entering the construction business.

70. Giffels Associates, Inc., Construction Management, Doc. No. 1180-CM2-1 (1978) (unpublished manuscript by a leading architect/engineer firm) (emphasis added) 